\title{
Assessment of Nutritional Status using Anthropometric Measurements in Relation to Pregnancy Outcome among Southern Sudanese Pregnant Mothers in Juba City, University of Bahri - Khartoum, Sudan
}

\author{
Siham Mohamed Osman Gritly ${ }^{1}$, Dr. Nada Ali Bahafizalla ${ }^{2}$ \\ Assistant Professor in the fields of Health and Nutrition, Khartoum Sudan
}

MD Dermatologist, Khartoum Sudan

\begin{abstract}
Maternal anthropometry has not yet received adequate attention in Sudan. The objectives are to evaluate the nutritional status of pregnant mothers in Juba area through anthropometric measurements, and relate them to pregnancy outcomes, using height, weight, mid upper arm circumference, biceps and triceps skin-fold thicknesses as indicators and to establish baseline data for future investigations and guidelines in the fields of maternal health care and community development. The study design it is a cross-sectional as well as longitudinal health facility- based study, carried out in Juba city. Methods the data consisted of interview guided by questionnaires, and anthropometric measurements. Results The mean height $162.59 \mathrm{~cm}$ and the mean weight $62.11 \mathrm{~kg}$. The mean mid upper arm circumference was $25.11 \pm 2.81 \mathrm{~cm}$. The mean biceps and triceps were $7.95 \pm 5.57 \mathrm{~mm}$ and $13.97 \pm 7.14 \mathrm{~mm}$ respectively. The mean maternal weight gain was $1.63 \pm 0.48 \mathrm{~kg} /$ month. The mean birth weight was $2.89 \pm 0.49 \mathrm{~kg}$ and the frequency of $\mathrm{LBW}(<2.5 \mathrm{~kg})$ was found to be very high (38.3\%). The highest birth weight found among Mundari tribe (3.1 $\pm 0.4 \mathrm{~kg})$. Conclusion; Strong significant association was found between birth weight and maternal height, maternal weight, mid upper arm circumference, triceps skin-fold thickness $(p<0.05)$.
\end{abstract}

Keywords: Anthropometric, Pregnancy outcome, Mid Upper Arm Circumference, Skinfold Thickness Low birth Weight

\section{Background}

Pregnancy is one of the most marvelous events and complex processes which occur among human beings. Since the prehistoric ages, people have paid a lot of care and attention to pregnancy and its related aspects. It is a natural process for living organisms to reproduce. The female reproductive organs are the site of reproduction. During the period of pregnancy numerous physiological changes occur in the mother.

Current maternal nutritional status, as measured by weight gain during pregnancy, may influence preterm delivery and gestation duration [1]. An analysis of study in 20 countries during and after pregnancy indicated that maternal weight gain and body composition are associated with the newborn birth weight and the influence of the birth weight on infant mortality [2]. Other study conducted in Brazil evaluated weight gain during pregnancy suggested that more effective means of managing weight gain during pregnancy are necessary to overcome the risk of obesity during pregnancy, and thus reduce the incidence of pre-eclamcia [3]. Siega-Riz, et al (1994) [4] found that women underweight before pregnancy (body mass index less than 19.8) had the greatest risk of delivering preterm. They concluded that weight monitoring during pregnancy continues to have clinical applications for the prediction of poor birth outcomes.

WHO, (1995) [5] suggested that the most widespread use of anthropometric measurements during pregnancy has been in evaluating the risk of fetal growth retardation and selecting women or populations for nutritional interventions aimed at improving fetal growth or prolonging gestation. It was also proposed that assessment during pregnancy is based on height, weight, mid-upper arm circumference and skin-fold thickness and that they might reflect past events, predict future events and indicate current nutritional status. They are also useful as indicators for concurrent socioeconomic inequity, risk, or response to an intervention, or predict which individuals will benefit from an intervention. The usefulness of using these indicators is suitable to clinical application, program implementation and management, policy and planning $[6,7,8,9,10,11]$.

Justification:

Although all effort from different national and international bodies in Sudan and southern Sudan oriented their attempt towards improving, the health of mother and child but the aims not achieved, according to the statistical data revealed by Sudan Federal Ministry of Health (2005) [12]. This is might be due to some of natural disasters, non-natural disasters and out control environmental factors. Sudan still suffers a decline in the field of health services as well as social wellbeing. There has been deterioration in economy, national health services and education. Nevertheless Sudan with its two parts have much concern for the maternal health but still there are lack for the essential health care services mainly in rural areas according to Sudan Federal Ministry of Health 2005 [12].

\section{Volume 4 Issue 11, November 2015}




\section{International Journal of Science and Research (IJSR) \\ ISSN (Online): 2319-7064}

Index Copernicus Value (2013): 6.14 | Impact Factor (2014): 5.611

There is lack of reliable information concerning relationships between anthropometric measurements and pregnancy outcomes in Sudan and the southern Sudan in particular. Adequate attention for identifying mothers at risk for developing small babies are lacking in Sudan. Few studies have dealt with the effect of various factors on maternal weight and birth weight and socio-cultural aspects in Sudan [13, 14,15, 16, 17, 18, 19, 20, 21, 22, 23]. However, there is a great need to carry out studies regarding anthropometric measurements in relation to infant weight. The WHO Collaborative Study on Maternal Anthropometry and Pregnancy Outcomes (1997) [24] showed that birth weights between 3.1 and $3.6 \mathrm{~kg}$, with a mean of $3.3 \mathrm{~kg}$, were associated with the optimal ratio of good foetal and maternal outcomes.

\section{Material \& Methods}

Anthropometrics measurements techniques:-

Cross-sectional maternal anthropometric measurements were taken from a total number of 300 pregnant women upon their consent. Those were weight, height, mid upper arm circumference, biceps and triceps skin-fold thickness. The researcher has taken all the measurements.

Weight and height were used to calculate body mass index. Mid upper arm circumference, triceps and biceps skin-fold thickness are used to calculate; Total Upper Arm Area, Mid Upper Arm Muscle Area, Mid Upper Fat Area, Arm Fat Index, Bone-Muscle Area. Fat mass and fat free mass were also calculated $[25,26,27]$

\section{1- Heights}

Heights of the mothers were taking during the time of data collection using plastic measurement. Pregnant women were asked to remove their shoes and her head and buttocks to the wall. All heights were recorded in the questionnaire sheet.

\section{2-Weight of mother}

Two measurements of weight have been recorded. Previous weight from the health record including weeks of gestation was observed. The second weight measurements have been taken during the interview by the researcher using balance beam scales. Weeks of gestation have been registered at the time of interview. Balance beam scale was placed in a hard and flat floor surface. At the beginning of each examination the scale was balanced to zero, using standardized weights to check up the scale and make any necessary corrections. Women were asked to remove their shoes, heavy handbags, and other heavy outer garments, and to stand in the center of the platform and to look straight.

\section{3-Biceps and Triceps skin fold-thickness}

Biceps and Triceps skin fold-thickness provide an estimate of the thickness of subcutaneous fat or amount of stored fat. Measurements have been done by the researcher using John Bull Caliper (British indicator limited). This was done by gripping the skin about $1 \mathrm{~cm}$ above the selected site and the calipers applied below this site, the grip is removed and the measurement was been taken, the caliper was then removed.

\section{4-Mid Upper Arm Circumferences}

This measurement has been taken by the researcher, using flexible but not stretchable measuring tape. MUAC measured at the mid-point of the upper arm between the shoulder and elbow (inferior tip of the olecranon). The measurement was taken to estimate; Total Upper Arm Area, Mid Upper Arm Muscle Area, Mid Upper Fat Area, Arm Fat Index, Bone-Muscle Area. Fat mass and fat free mass.

Formulas used;

For more information on lean mass and fat mass reserves we used Total Upper Arm Area, Mid Upper Arm Muscle Area, Mid Upper Fat Area, Arm Fat Index, Bone-Muscle Area, Fat Mass and Total Fat Free Mass were used with other variables to assess nutritional status using the following equations; [25,26, 27, 8,7].

1-Total Upper Arm Area= MUAC2 / 4× 3.14 [8]

2-Mid Upper Arm Muscle Area $=\{$ MUAC- $(3.14 \times$ Triceps $)\} 2$ / $(4 \times 3.14)-6.5$ [7]

3-Mid Upper Arm Fat Area =Total Upper Arm Area - Mid Upper Arm Muscle Area [7]

4-Arm Fat Index $(\%)=($ Mid Upper Arm Area $/$ Total Arm Area) $\times 100$ [7]

5-Bone Muscle Area=1/4×3.14 \{MUAC- (3.14/2)(Triceps + Biceps) 2 [27]

6 -Fat Free Mass $=(0.287 \times$ Weight"kg" $)+(9.74 \times$ Height"msq $)$ [25]

7-Fat Mass $=$ Weight of mother- Fat Free Mass [25].

\section{Result}

This study was designed to determine the nutritional status of pregnant mothers and pregnancy outcome by using anthropometric techniques. Three hundred pregnant southern women in their second and third trimesters participated in this study after their consent. Data collected from three places, the main hospital (Juba Teaching Hospital) and two other health centers around the area (Kattwor and Kuwait). Infant birth weights were obtained from only 257 in which 14 of the deliveries were twins. Twins' birth weights were excluded from the calculations of birth weight, consequently only 243 infant weights included in the final data analysis. The results of this longitudinal as well as cross sectional study were presented in tables and charts using SPSS. Results were represented in tables and graphs

Table 1: Socio-demographic profile

\begin{tabular}{|c|c|c|}
\hline \multicolumn{3}{|c|}{ Name Of Hospital \& Health Centers } \\
\hline Juba hospital & 200 & 66.7 \\
\hline Kattwor health centre & 69 & 23 \\
\hline Kuwait health centre & 31 & 10.3 \\
\hline Total & 300 & 100 \\
\hline Weeks of gestation & No & $\%$ \\
\hline 12-25 weeks (mothers in the second trimesters) & 127 & 42.3 \\
\hline 26-37-40weeks (mothers in the third trimesters) & 173 & 57.7 \\
\hline Total & 300 & 100 \\
\hline
\end{tabular}




\section{International Journal of Science and Research (IJSR) \\ ISSN (Online): 2319-7064 \\ Index Copernicus Value (2013): 6.14 | Impact Factor (2014): 5.611}

Table 1 describes the general information of the samples. The majorities of samples were from the main hospital in Juba city $(66.7 \%)$ where $23 \%$ and $10.3 \%$ were randomly chosen from Kattwor and Kuwait health centers. About $42.3 \%$ of mothers examined were in their second trimesters and about $57.7 \%$ were in their third trimesters as shown in the above table (table A-1).

Table (3): Live birth weights

\begin{tabular}{|c|c|c|c|c|}
\hline Birth Weight (k) & No & $\%$ & Mean & SD \\
\hline Less than $2.50 \mathrm{~kg}$ & $\mathbf{9 3}$ & $\mathbf{3 8 . 3}$ & & \\
\cline { 1 - 3 } $2.50-3.99 \mathrm{~kg}$ & $\mathbf{1 4 5}$ & $\mathbf{5 9 . 7}$ & & \\
\hline More than $3.99 \mathrm{~kg}$ & $\mathbf{5}$ & $\mathbf{2 . 0}$ & & \\
\cline { 1 - 3 } Total live birth & $\mathbf{2 4 3}$ & $\mathbf{8 1 \%}$ & $\mathbf{2 . 8 9}$ & $\mathbf{. 4 9 6}$ \\
\hline
\end{tabular}

Up to $59.7 \%$ of mothers delivered babies weighing 2.5-3.99 $\mathrm{kg}$. And $38.3 \%$ gave birth to babies weighing less than 2.5 (low birth weight). Up to $2 \%$ delivered babies weighing more than $3.99 \mathrm{~kg}$. Over weight babies were noted. The mean birth weight was $2.89 \pm .496 \mathrm{~kg}$ (table 3 ).

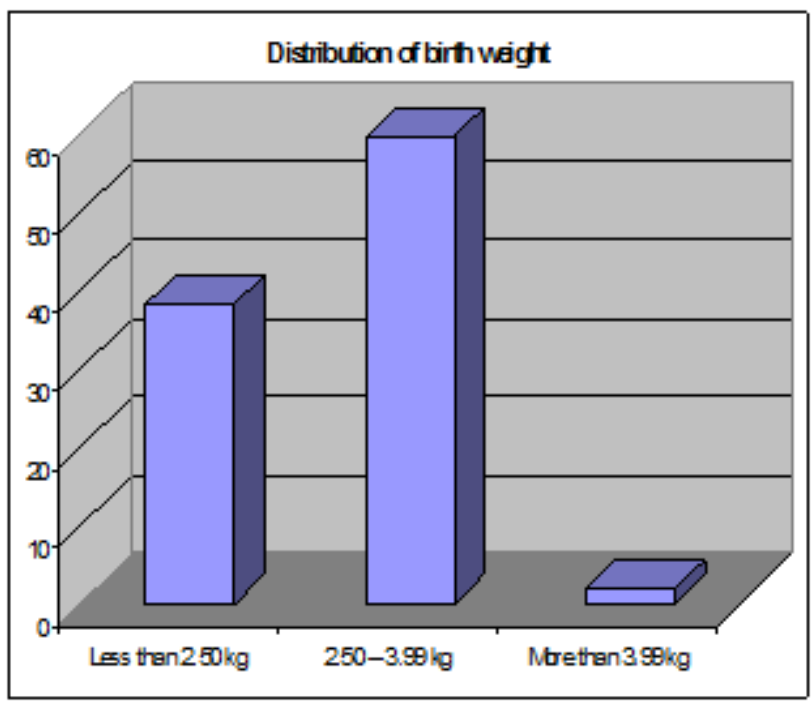

Figure 1: Distribution of birth weight

Table 4: Anthropometrics measurement of pregnant mothers in Juba city

\begin{tabular}{|c|c|c|c|c|}
\hline Anthropometric measurements & No & $\%$ & Mean & SD \\
\hline \multicolumn{5}{|l|}{ Maternal height } \\
\hline Less Than $148 \mathrm{~cm}^{*}$ & 3 & 3.3 & \multirow[t]{2}{*}{162.59} & \multirow[t]{2}{*}{7.50} \\
\hline $148 \mathrm{~cm}$ More Than & 297 & 96.7 & & \\
\hline \multicolumn{5}{|l|}{ Maternal weight } \\
\hline$<45 \mathrm{~kg}$ & 3 & 3.3 & \multirow[t]{2}{*}{62.11} & \multirow[t]{2}{*}{10.53} \\
\hline$\geq 45 \mathrm{~kg}$ & 297 & 96.7 & & \\
\hline \multicolumn{5}{|l|}{ Mid upper arm circumference (cm) } \\
\hline Under weight $<23.3 \mathrm{~cm}$ & 84 & 28 & \multirow{3}{*}{25.11} & \multirow{3}{*}{2.81} \\
\hline Normal weight $23.3-25 \mathrm{~cm}$ & 94 & 31.3 & & \\
\hline Over weight $>25 \mathrm{~cm}$ & 122 & 40.7 & & \\
\hline Triceps skin-fold thickness $(\mathbf{m m})$ & 300 & 100 & 13.97 & 7.14 \\
\hline Biceps skin-fold thickness (mm) & 300 & 100 & 7.95 & 5.57 \\
\hline
\end{tabular}

Table 4 describes the different anthropometric measurements. The majority $(96.7 \%)$ of pregnant mothers' heights were found to be more than $148 \mathrm{~cm}$ with a mean of $162.59 \pm 7.50 \mathrm{~cm}$. the weight mean $62.11 \pm 10.53 \mathrm{~kg}$. The mean MUAC was $25.11 \pm 2.81$. The majority of mothers (59\%, no=178 with mean of 23.3) had MUAC less than $25 \mathrm{~cm}$. Using the mean of mid upper arm circumference of the group with less than $25 \mathrm{~cm}$ we identified new cut-off for this group. <23.3 under normal cut-off (28\%), 23.3-25 within the normal range $(31.3 \%)$, and more than $25 \mathrm{~cm}$ were identified as over nutrition $(40.7 \%)$. The mean average of biceps was $7.95 \pm 5.07 \mathrm{~mm}$ and the mean of triceps was found to be $13.97 \pm 7.14 \mathrm{~mm}$.

Table 5: Distribution of some of the calculated anthropometric indices according to trimesters

\begin{tabular}{|c|c|c|c|c|c|c|}
\hline \multirow{2}{*}{ Variables } & \multicolumn{2}{|c|}{ Second trimester } & \multicolumn{2}{c|}{ Third trimester } & \multicolumn{2}{c|}{ Total } \\
\cline { 2 - 7 } & Mean & SD & Mean & SD & Mean & SD \\
\hline Total Upper Arm Area $\left(\mathrm{cm}^{2)}\right.$ & 50.49 & 10.97 & 51.09 & 12.40 & 50.83 & 11.7 \\
\hline Mid Upper Arm Muscle Area $\left(\mathrm{cm}^{2}\right)$ & 28.06 & 8.87 & 28.25 & 7.59 & 28.17 & 8.1 \\
\hline Mid Upper Fat Area $\left(\mathrm{cm}^{2}\right)$ & 22.43 & 7.73 & 22.83 & 9.92 & 22.66 & 9.03 \\
\hline Arm Fat Index $(\%)$ & 44.58 & 12.34 & 43.95 & 11.38 & 44.21 & 11.7 \\
\hline Fat Free Mass $(\mathrm{kg})$ & 33.58 & 3.36 & 33.72 & 3.42 & 33.66 & 3.40 \\
\hline Fat mass $(\mathrm{kg})$ & 28.26 & 7.2 & 28.57 & 7.24 & 28.44 & 7.21 \\
\hline Bone muscle area & 6.27 & 10.59 & 3.47 & 20.78 & 4.68 & 17.2 \\
\hline
\end{tabular}

Table 5 describes means and standard deviation of some of anthropometric variables. Those variables are Total Upper Arm Area (mean50.83 $\pm 11.7 \mathrm{~cm}^{2}$, Mid Upper Arm Muscle Area $\left(28.17 \pm 8.1 \mathrm{~cm}^{2}\right)$, Mid Upper Fat Area $\left(22.66 \pm 0.03 \mathrm{~cm}^{2}\right.$,) Arm Fat Index $(44.21 \% \pm 11.7)$, Fat Mass
$(18.4 \pm 6.8 \mathrm{~kg})$ and Total Fat Free Mass $(43.63 \pm 4.54 \mathrm{~kg})$. the calculated values indicate the body composition and to provide more information about energy and muscle protein. From the above observations we found increase of values of these variables during third trimester where as bone

\section{Volume 4 Issue 11, November 2015} www.ijsr.net 


\section{International Journal of Science and Research (IJSR) \\ ISSN (Online): 2319-7064}

Index Copernicus Value (2013): 6.14 | Impact Factor (2014): 5.611

muscle area and upper arm fat index show decreased during the third trimester.

Table 6: Correlations between infant weight and anthropometric indices

\begin{tabular}{|l|c|c|}
\hline \multirow{2}{*}{ Anthropometric Measurements } & \multicolumn{2}{|c|}{ birth weight } \\
\cline { 2 - 3 } & $R$ & $P_{-}$value \\
\hline Maternal Height & .205 & .001 \\
\hline Weight of Mother & .382 & .000 \\
\hline Midd Upper Arm Circumference & .437 & .000 \\
\hline Triceps & .348 & .000 \\
\hline Biceps & .283 & .011 \\
\hline
\end{tabular}

*Correlation Significant in 0.05 level

** High Correlation Significant in 0.01 level

Table 6 shows strong positive correlation between infant birth weight and maternal height $(r=.205, \mathrm{p}<0.01)$ maternal weight $(\mathrm{r}=.382, \mathrm{p}<0.01)$, mid upper arm circumference $(\mathrm{r}=.437, \mathrm{p}<0.01)$, triceps $(\mathrm{r}=.348, \mathrm{p}<0.01)$ and biceps $(\mathrm{r}=.283, \mathrm{p}<0.05)$ skin fold thickness. This result shows the importance of using anthropometrics during pregnancy for quick nutritional status assessment to identify women at risk for appropriate intervention.

Table 7: Classification of birth weight according to the mid upper arm circumference values;

\begin{tabular}{|c|c|c|c|c|}
\hline Variable & No & $\%$ & $\begin{array}{c}\text { Mean birth } \\
\text { weight }\end{array}$ & SD \\
\hline Mid upper arm circumference & & & & \\
\hline Under weight $<23.3 \mathrm{~cm}$ & 69 & 28.39 & 2.65 & .427 \\
\hline Normal weight $23.3-25 \mathrm{~cm}$ & 76 & 31.27 & 2.83 & .432 \\
\hline Over weight $>25 \mathrm{~cm}$ & 98 & 40.32 & 3.11 & .487 \\
\hline
\end{tabular}

Table 7 shows the relation between different mid upper arm circumference values and birth weight, with MUAC less than $23.3 \mathrm{~cm}$ the birth weight is $2.65 \pm 0.42 \mathrm{~kg}$. with MUAC more than $25 \mathrm{~cm}$ the birth weight is $3.11 \pm 0.48 \mathrm{~kg}$ (total examined $n=243$ live birth).

Table 8: Correlation between birth weight and body composition of the mother as calculated from mid upper arm circumference, biceps and triceps skin-fold thicknesses

\begin{tabular}{|c|c|c|}
\hline \multirow{2}{*}{ Variables } & \multicolumn{2}{|c|}{ Infant birth weight } \\
\cline { 2 - 3 } & $\mathrm{R}$ & P Value \\
\hline Total upper arm area $\left(\mathrm{cm}^{2}\right)$ & .429 & .000 \\
\hline Mid Upper Arm Muscle Area $\left(\mathrm{cm}^{2}\right)$ & .248 & .000 \\
\hline Mid Upper Fat Area $\left(\mathrm{cm}^{2}\right)$ & .345 & .000 \\
\hline Arm Fat Index $(\%)$ & .099 & .125 \\
\hline Bone-Muscle area $\left(\mathrm{cm}^{2}\right)$ & -.246 & .000 \\
\hline Fat Mass $(\mathrm{kg})$ & .325 & .000 \\
\hline Fat Free Mass $(\mathrm{kg})$ & .303 & .000 \\
\hline
\end{tabular}

*Correlation Significant in 0.05 level
** High Correlation Significant in 0.01 level

Positive correlation was observed between infant birth weight and total arm upper area $(r=.429, \mathrm{p}<.01)$, mid upper arm muscle area $(\mathrm{p}<.001)$, mid upper arm fat area $(\mathrm{p}<.001)$, fat mass and fat free mass at $\mathrm{p}<.001$, while no correlation was observed between infant birth weight and percentage of upper arm fat on the other hand negative association was observed between infant weight and bone-muscle area (table 8). Estimation of the arm fat index, or percent fat area is used for providing additional estimation of maternal fats. While mid upper arm muscle circumference and mid upper arm muscle area can predict changes in total muscle mass and therefore protein nutritional status or lean body mass. The fat free mass can provide an estimation of muscle protein reserve of the body.

\section{Discussion}

Anthropometric measurements were used in this study to assess body composition and pregnancy outcome of mothers in Juba area and relate them to birth weight. The anthropometric measurements used in this study were; height, weight, BMI, weight gain, mid upper arm circumferences, biceps and triceps skin-fold thicknesses in addition to other anthropometric indices calculated from mid upper arm circumference, triceps and biceps skin-fold thickness. All these variables were used as indicators for birth weight and mothers' nutritional status.

\section{Height \&Weight}

The majority of mothers in this study had height more than $145 \mathrm{~cm}(96.7 \%)$ with the mean of $162.59 \pm 7.50 \mathrm{~cm}$ which were more than the suggested cut-off point proposed by WHO for normal height. The results indicate that the majority of mothers have normal height for normal pregnancy (Table B1-1). Makki, (2000) [13] found the mean height of pregnant mothers in Omdurman was $160 \pm 7.77 \mathrm{~cm}$. When compared with our result we found that the mothers was taller than the above study. A study in Tanzania suggested that maternal stature under $150 \mathrm{~cm}$ is associated with an increased risk of obstructed labor [28]. On the other hand $[29,30]$, indicated that height of $=160 \mathrm{~cm}$ or less might indicate risk of cesarean delivery.

The majority of mothers $(77.7 \%)$ had weight more than 54 $\mathrm{kg}$. The mean weight was $62.11 \pm 10.53 \mathrm{~kg}$ during the second trimester was $61.84 \pm 10.49 \mathrm{~kg}$ and that during third trimester was $62.29 \pm 10.57 \mathrm{~kg}$. A study in Omderman [13] showed mean weight among pregnant mothers during second and third trimesters were $58.5 \pm 9.27 \mathrm{~kg}$ and $61.5 \pm 9.63 \mathrm{~kg}$ respectively. Comparison may not be easy because of heterogeneity of the samples and socio-economic differences.

Mid upper arm circumference and skin-fold thicknesses The average total mean of mid upper arm circumference (MUAC) among the studied group was $25.11 \pm 2.81 \mathrm{~cm}$. The majority of mother (59\%) had mid upper arm circumference more than $25 \mathrm{~cm}$. about $31 \%$ of mothers had MUAC

\section{Volume 4 Issue 11, November 2015 www.ijsr.net}




\section{International Journal of Science and Research (IJSR) \\ ISSN (Online): 2319-7064 \\ Index Copernicus Value (2013): 6.14 | Impact Factor (2014): 5.611}

between 23.5-25 $\mathrm{cm}$ and $28 \%$ had MUAC less than $23.5 \mathrm{~cm}$. It is concluded that the prevalence of under nourished mother are high (28\%).

Table 4 described birth weight according to different MUAC values. MUAC less than $23.5 \mathrm{~cm}$, the birth weight was $2.65 \pm 0.42 \mathrm{~kg}$, MUAC between 23.5-25 cm the birth weight was $2.83 \pm 0.43 \mathrm{~kg}$ and MUAC more than $25 \mathrm{~cm}$ the birth weight was found to be $3.11 \pm 0.48 \mathrm{~kg}$. We suggested that MUAC more $25 \mathrm{~cm}$ could be best indicator for predicting birth weight among the pregnant mothers. Mothers with MUAC more than $25 \mathrm{~cm}$ delivered babies weighing more than $3 \mathrm{~kg}$. James et al, (1994) [31] suggested that MUAC values of $22.0 \mathrm{~cm}$ in women are useful cut-off points for simple screening of nutritional status. Mid upper arm circumferences is an indicator of fat and muscles in the upper arm. It can also be used as measurement of body protein [7]. MUAC Cut-off points have been suggested by different studies for prediction of pregnancy outcomes as in Bangladesh $<22.5 \mathrm{~cm}$ MUAC was associated with Neonatal morbidity, Brazil $<23.5 \mathrm{~cm}$ (Low birth weight), Chile $24 \mathrm{~cm}$ (IUGR), Guatemala <22.5 cm (Low birth weight) (WHO, 1996) [32].

\section{Skin-Fold Thickness}

This study found the mean value of biceps skin fold thickness was $7.95 \pm 5.07 \mathrm{~mm}$ and the mean of triceps was found to be $13.97 \pm 7.14 \mathrm{~mm}$. A study in Cleveland, Ohio USA, found that during late gestation the biceps skin fold thickness were $8.6 \pm 5.1 \mathrm{~mm}$ and triceps $18.8 \pm 4.7 \mathrm{~mm}$ [33]. The biceps and triceps skin-fold thicknesses mean values were below the above values suggested by some researchers.

Mohanty et al (2006) [34] indicated that anthropometric indicators are useful predictors of low birth weight (LBW). Positive correlations were observed among maternal weight. Maternal height, maternal mid-arm circumference and maternal body mass index were all correlated with birth weight during both second and third trimesters. They concluded that the most sensitive indicators for prediction of LBW were maternal weight below $45 \mathrm{~kg}$, followed by maternal mid-arm circumference less than $22.5 \mathrm{~cm}$, maternal height below $152 \mathrm{~cm}$ and maternal body mass index less 20 $\mathrm{kg} / \mathrm{m} 2$.

\section{Derived Anthropometric Indices}

For additional information of pregnant body composition for fat mass and muscle protein reserves we used mid upper arm circumference, biceps and triceps skin-fold thickness to calculate other anthropometric indices. We found that the mean of total upper arm area $50.83 \pm 11.7 \mathrm{~cm} 2$, mid upper arm muscle area $(28.17 \pm 8.1 \mathrm{~cm} 2)$, mid upper fat area $(22.66 \pm 0.03 \mathrm{~cm} 2$,$) arm fat index (44.21 \% \pm 11.7)$, muscle bone area $4.68 \pm 17.2$, fat mass $(18.4 \pm 6.8 \mathrm{~kg})$ and fat free mass $(43.63 \pm 4.54 \mathrm{~kg})$. The arm muscle area is suggested as a good indicator for the lean body mass and thus for the skeletal protein reserves. There are limited studies in Sudan for the variables above during pregnancy so these data might be useful as an standard values for future investigations.
Different anthropometric indices in relation to trimesters revealed that during second and third trimesters the values of mid upper arm muscle area (MUAMA), mid upper arm fat area (MUAFA), mid upper arm area (MUAA), arm fat index, bone muscle area, fat mass and fat free mass were similar. The above comparison of maternal body composition in the second and third trimesters indicate that the pregnancy demands did not significantly affect either the muscles or fat stores, These variables were used to provide more information about energy and muscle protein. However, previous studies of $[7,33,34,27]$ and more others studied the usefulness of anthropometric and derived anthropometric measurements in assessing fat mass and fat free mass (nutritional status).

\section{Birth weight findings}

The mean birth weight is found to be $2.89 \pm 0.49 \mathrm{~kg}$ among pregnant mothers in Juba city (two hundred and forty three live births). This mean birth weight was lower than that found in the two previous studies carried out in Omdurman city which reported a mean birth weight of $3.02 \pm 0.49 \mathrm{~kg}$ for both genders [13], and $3.2 \pm .48 \mathrm{~kg}$ [36]. Another study in Bengalee found that the birth weight was $2.59 \pm 0.371 \mathrm{~kg}$. Among boys, mean birth weight was $2.65 \pm 0.362 \mathrm{~kg}$, while among girls it was $2.51 \pm 0.367 \mathrm{~kg}$ [37]. Other study suggested that LBW is strongly associated with infant mortality, especially among neonate [38]. There is some indication that it is also related to preschool mortality rates (1-4 years). Using $<2.5 \mathrm{~kg}$ in full-term infant as cut off points for low birth weight we concluded that, the prevalence of low birth weight (LBW) is very high among the pregnant mothers in this study $(38.3 \%)$. Effort should be directed towards improving the health and nutritional status of this and similar groups of mothers as part of national policies.

\section{Conclusions}

- The mother's height showed significant correlation with infant birth weight at $\mathrm{p}<0.01$ level. The majority of mother $(96 \%)$ had height more than the height recognized by World Health Organization.

- Mid upper arm circumference, biceps, and triceps showed strong positive correlation with birth weight which confirms conclusion no. 6 . The strongest correlation was found with mid upper arm circumference.

- High prevalence of malnourished mothers was observed. Under weight mother with body mass index $(23.1 \mathrm{~kg} / \mathrm{m} 2)$ during second trimester< was $(62.2 \%)$, and during third trimester was $(78 \%)$

13-Multiple linear regression analysis was used to estimate the magnitude of the effect of all variables at one time on pregnancy outcome (birth weight). The strongest indicative variables were found to be the mid upper arm circumference. total arm upper area $(r=.429, \mathrm{p}<.01)$, mid upper arm muscle area $(\mathrm{p}<.001)$, mid upper arm fat area $(\mathrm{p}<.001)$, fat mass and fat free mass at $p<.001$, while no correlation was observed between infant birth weight and percentage of upper arm fat on the other hand negative association was observed between infant weight and bone-muscle area. Estimation of

\section{Volume 4 Issue 11, November 2015}

www.ijsr.net 


\section{International Journal of Science and Research (IJSR) \\ ISSN (Online): 2319-7064}

Index Copernicus Value (2013): 6.14 | Impact Factor (2014): 5.611

the arm fat index, or percent fat area is used for providing additional estimation of maternal fats. While mid upper arm muscle circumference and mid upper arm muscle area can predict changes in total muscle mass and therefore protein nutritional status or lean body mass. The fat free mass can provide an estimation of muscle protein reserve of the body.

\section{References}

[1] Scholl, O. Theresa, Mary L. Hediger, Ruth W. Salmon, Daniel H. Belsky, Isadore G. Ances. 1989. Influence of prepregnant body mass and weight gain for gestation on spontaneous preterm delivery and duration of gestation during adolescent pregnancy. American Journal of Human Biology, 1(6):657-664.

[2] Kelly, A.; Kevany J.; de Onis M.; Shah PM. 1996. A WHO Collaborative Study of Maternal Anthropometry and Pregnancy Outcomes. Int J Gynaecol Obstet., 53(3):219-233.

[3] Luciana, BN.; Bruce BD.; Sotero SM.; Leandro B.; Maria IS. and Eni TF. 2001. Assessment of weight gain during pregnancy in general prenatal care services in Brazil. Cad. Saude Publica. Rio de Janeiro, 17(6):1367.

[4] Siega-Riz AM.; Adair LS. and Hobel CJ. 1994. Maternal weight gain recommendations and pregnancy outcome in a predominantly Hispanic population. Obstetrics \& Gynecology; 84:565-573.

[5] World Health Organization 1991. Maternal anthropometry for prediction of pregnancy outcomes: memorandum from US Agency for International Development/WHO/PAHO/Mother Care meeting. Bull World Health Organ, 69:523-32.

[6] Mardones FS.; Salazar G.; Rosso P. and Villarroel L, 1998. Maternal body composition near term and birth weight. Obstetrics \& Gynecology, 91:873-877.

[7] Frisancho, AR. 1990. Anthropometric Standards for the Assessment of Growth and Nutritional Status. Ed.Ann Arbor, University of Michigan, USA.

[8] Heymsfield B. Steven, Ann Tighe and Zi-Mian Wang. 1994. Nutritional Assessment by Anthropometric and Biochemical Methods. In Modern Nutrition in Health and Disease. 8th edition, volume 1 . Edited by Maurice E. Shils, James A. Olson and Moshe Shike., pp 812-838

[9] Abrams, B. and Selvin S. 1995. Maternal weight gain pattern and birth weight, Obstetrics \& Gynecology, 86:163-169.

[10] Nahar S, Mascie-Taylor CG, Begum HA. 2007. Maternal anthropometry as a predictor of birth weight. Public Health Nutr., 10(9):965-970.

[11]Forbes, BG. 1999. Body composition: Influence of Nutrition, Physical Activitiy, Growth and Aging: IN Modern Nutrition in Health and Disease; Shils E Maurice, Olson A. James, Shike Moshe and Ross A. Catharine eds. 9th edition, Lippincott Williams and Willkins, USA. pp 789-805.

[12]Federal Ministry of Health. 2005. National Health Information Centre. Annual Health Statistical Report, Sudan.

[13] Makki FA. 2000. The effect of maternal nutritional status on the infant birth weight. UV. of Khartoum, Faculty of Education, Home Science dept. A thesis submitted in a partial fulfillment of requirement of Degree in Msc in science.

[14]El Hiday, MM. and Zumrawi FY. 1992. The Effect of Nutrition Education Program on Pregnant Women. Ahfad Journal; 9(2): 23-36.

[15] Bouchier, VA. 1984. Maternity care in the Sudd, southern Sudan. Tropical Doctor, 14(1):32-33.

[16]Eltom, AO. and ElSafi A. 1988. Traditional Practices Affecting the Health of Pregnant women and Children. Traditional and Medicine Research Institute. KhartoumSudan.

[17]Eltayeb, Ahmed Eltayeb. 1997. Serum Ferritin in Normal Subjects and Assessment of Iron Status during Pregnancy. University of Khartoum, Sudan.

[18] Mohammed FH. 2003 Influence of Short Birth Spacing on Pregnancy Outcome. Faculty of Medicine, University of Khartoum, Sudan.

[19] Brigdar Y. ND Abbas Mohammed. 1997. Impact of Maternal Employment during Pregnancy on Birth Weight and Duration of Pregnancy. University of Khartoum, $\mathrm{PhD}$, thesis.

[20] Yassin, IM. 1996. Impact of low Socio-Ecnomic Status on Fetal Outcome in a Term Pregnancy. University of Khartoum, Department of Obstetric and Gynaecology.

[21] Osman, AK. 1985. Dietary Practices and Aversion during Pregnancy and Lactation among Sudanese Women. Journal of Tropical Pediatrics; 31(1):16-20.

[22] Ostrowski ZL 1982. Longitudinal Nutritional Study in Pregnant women and Early Childhood in Jongali Canal. First International Round Table Conference on Nutrition Status of Pregnant Women in Sudan. Association for Studies on Nutrition and Child Development, 22-38.

[23] Safi, Al. Ahmed, 2007 Traditional Sudanese Medicine. First edition. El Sudan: Dar Azza, Sudan, pp; 188- 202.

[24] The WHO Collaborative Study on Maternal Anthropometry and Pregnancy Outcomes (1997)

[25] Garrow, JS. Webster J. 1985. Quetelet's Index (W/H^2) as a measure of fatness. Int J Obestiy, 9: 147-153

[26] Khadivzadeh, T. 2002. Mid upper arm and calf circumferences as indicators of nutritional status in women of reproductive age. East Mediterr Health J, 8(4\&5):612-618.

[27] Heymsfield, SB.; Baumgartner N.; Richard and SheauFang P. 1999. Nutritional assessment of Malnutrition by Anthropometric Methods. In: Modern Nutrition in Health and Disease; Shils E Maurice, Olson A. James, Shike Moshe and Ross A. Catharine eds. 9th edition; $p$ 903-921.

[28] Lindmark, B. Moller G. 1997. Short stature: an obstetric risk factor? A comparison of two villages in Tanzania. Acta Obstet Gynecol Scand, 76:394-397.

[29] Prasad M. and Al-Taher H. 2002. Maternal height and labour outcome. Journal of Obstetrics and Gynaecology, 22(5): $513-515$.

[30] Prasad M. and Al-Taher H. 2002. Maternal height and labour outcome. Journal of Obstetrics and Gynaecology, 22(5): $513-515$.

[31] James, WP; Mascie-Taylor GC; Norgan NG; Bistrian BR; Shetty PS. and Ferro-Luzzi A. 1994. The value of arm circumference measurements in assessing chronic energy deficiency in Third World adults. Eur J Clin Nutr., 48(12):883-894. 32-WHO, 1996).

\section{Volume 4 Issue 11, November 2015 www.ijsr.net}




\section{International Journal of Science and Research (IJSR) \\ ISSN (Online): 2319-7064}

Index Copernicus Value (2013): 6.14 | Impact Factor (2014): 5.611

[32] Presley LH.; Wong W.; Roman NM.; Amini SB. and Catalano PM. 2000. Anthropometric Estimation of Maternal Body Composition in Late Gestation. Obstetrics \& Gynecology, 96:33-37

[33] Mohanty, C.; Rajniti PA.; Srikanth R.; Jayant K.; Ghoshb, TB.; Singhc and Dasb BK.. 2006. Maternal Anthropometry as Predictors of Low Birth Weight. Tropical Pediatrics, 52(1):24-29.

[34] Presley LH.; Wong W.; Roman NM.; Amini SB. and Catalano PM. 2000. Anthropometric Estimation of Maternal Body Composition in Late Gestation. Obstetrics \& Gynecology, 96:33-37

[35] Shommo, AS. 2007. The relationship between Microutrients, $\mathrm{Fe}, \mathrm{Zn}$, and vitamin $\mathrm{A}$ to Maternal Dietary Intake and their New Borne., $\mathrm{PhD}$ thesis, University of Khartoum, Sudan

[36] Bisai, S; Amitava S; Mahalanabis D; Nandini D. and Kaushik B. 2006. The Effect of Maternal Age and Parity on Birth Weight among Bengalees of Kolkata, India. Human Ecology, 14: 139-143.

[37] Martorell R. and González-Cossío T. 2007. Maternal nutrition and birth weight. Wiley-Liss, Inc. USA.

Volume 4 Issue 11, November 2015

www.ijsr.net

Licensed Under Creative Commons Attribution CC BY 